\title{
Some Findings on Informatics Education in Austrian Academic Secondary Schools
}

\author{
Peter MICHEUZ \\ University Klagenfurt, Institute for Informatics-Systems \\ Universitätsstraße 65, 9020 Klagenfurt, Austria \\ e-mail:peter.micheuz@uni-klu.ac.at
}

Received: September 2007

\begin{abstract}
The educational system in Austria is very multifaceted, and academic secondary schools represent an important part in it. This type of schools, in German called "Gymnasium", covers the age-group from 10 to 18 years and provides pupils and students with a broad and general education. For more than twenty years, informatics and computers have increasingly penetrated into secondary education. Austrian academic secondary schools have much freedom to cope with this challenging task within their autonomy. In this paper, a snapshot of the current situation is given with the main emphasis on the 9th grade. Only in this age-group, the "PISA-age", informatics is a compulsory subject. The implementation of additional IT/informatics classes at lower secondary level is exclusively the result of autonomous decisions in schools. Recently, a web-based nationwide online research has been conducted. In this paper some preliminary results are presented.
\end{abstract}

Keywords: informatics, secondary education, curricula, online-survey, web-based research.

\section{Introduction}

Information technology does not change informatics, but it has an influence on how we deal with informatics

Doubtlessly, the information and knowledge society is exerting a considerable influence on education (in schools) in general and on secondary education in special. Among all subjects, informatics in Austrian schools and its related disciplines are still a matter of concern and development, especially in vocational schools. Policy makers are quite aware of the fact that every school has to provide the pupils with profound knowledge and skills with regard to IT and informatics. This does not apply only to vocational schools but also for schools imparting general education (Fig. 1).

The Austrian school system encompasses elementary (grades 1-4), lower secondary (grades 5-8) and upper secondary level (grades 9-12/13). This paper deals mainly with informatics as a subject of its own at lower secondary level, especially for the grades 5 to 9, comprising the age-groups from 10 to 15 .

At the lower secondary level the Austrian school system is currently divided into two types of schools, that is general secondary school "Hauptschule (HS)" and academic secondary school "Gymnasium (AHS, Allgemein bildende höhere Schule)". About two 


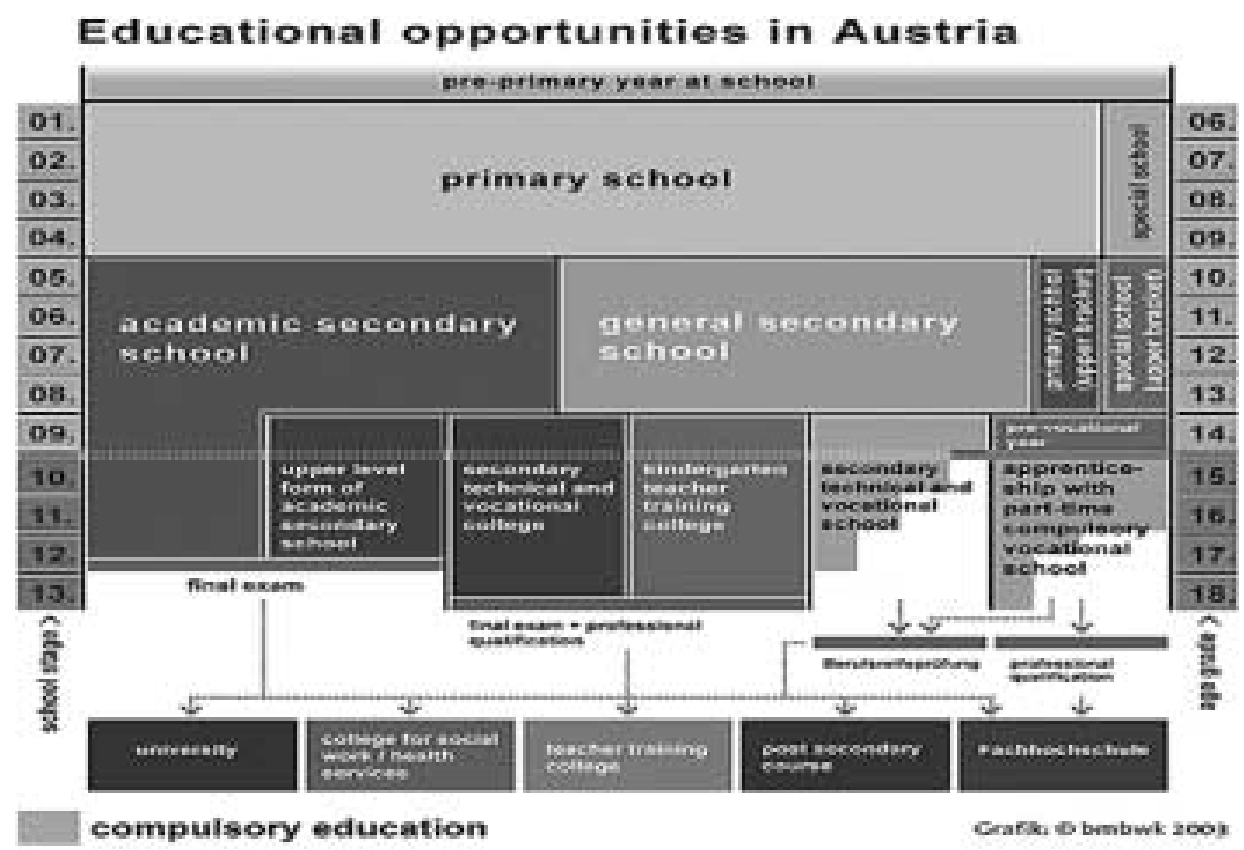

Fig. 1. The Austrian school system.

thirds of the 10-14-year old pupils attend HS and about one third attend the lower level of the AHS for four years. There is no comprehensive education in this age-group. Usually but not necessarily, cognitively more gifted pupils attend academic secondary schools. These are designed to consolidate and reinforce a comprehensive general education and to prepare students for university-level studies.

Beginning with the early nineties of the last century, the subject informatics has been implemented at secondary lower level for 10-14-year old pupils in various forms, but it was never compulsory for all pupils.

In the HS as well as in the AHS the penetration of informatics education was strongly dependent on engaged teachers and school administrators. At that time also the first attempts were made to integrate the application of computers in other subjects. In retrospective, this top down enactment, the success of the so called ITG ("Informationstechnische Grundbildung"), was never evaluated. It can be assumed that the integration of computers into other subjects never worked satisfactorily and on a large scale (Micheuz, 2005).

So far, especially the lower secondary level in Austria can be seen as a patchwork with regard to an overall systematic supply of IT/informatics knowledge and skills. As a result, students who enter the 9th grade at the beginning of upper secondary level have very diverging IT knowledge. Considering the task of schools to provide pupils with adequate computer literacy in time, this situation should be reflected.

It is obvious that information technology has dramatically changed the world outside our schools and is still changing the processes of teaching and learning within them. Nevertheless, Rod Paige, U.S. Secretary of Education, states that "Education is the only 
business still debating the usefulness of technology. Schools remain unchanged for the most part, despite numerous reforms and increased investments in computers and networks." The survey "Key data on ICT in schools in Europe" reveals that at the age of 15 a majority of European pupils claim to use computers in schools regularly. But the presence of computers at school does not guarantee that they are really used. Moreover, the PISA study for the year 2003 (Pisa, 2005) shows that the regularity of using the computer in school activities is still very heterogeneous across all investigated countries. While in some countries about two-thirds of the 15-year-old pupils are using computers at schools once or several times a month, there are big differences between countries and also between various schools within a country.

According to a modern definition of basic cultural tools and techniques, the classical areas such as "mastering the common language", "mathematical modeling competence", "competence in at least one foreign language" should be supplemented with "IT-competency" and "self regulation of acquisition of knowledge" (Baumert, 2003). We have to abandon the misconception that a modern canon of education can exist without basic IT-knowledge and -skills. Therefore IT and its corresponding subject informatics have to be considered as indispensable parts in every educational process.

There is a general consensus among the public and policy makers that pupils and students need to be "computer literate." The acquisition of IT competency and computer literacy requires an educational process and does not take place somewhere but needs schooling (Micheuz, 2007).

"Can a student who operates a computer well enough to play a game, send email or surf the Web be considered computer literate? Will a student who uses computers in school only for running tutorials or an integrated learning system have the skills necessary to perform well in our society? Will the ability to do basic word processing be sufficient for students entering the workplace or post-secondary education?" The answer is "clearly not" (Eisenberg, 2002).

Which accountability do national educational systems have to assure that all pupils at the end of their compulsory education are well prepared for succeeding in our digital society? This issue has not been addressed by responsible Austrian policy makers consequently enough, although about twenty years ago, the Austrian ministry of education implemented the compulsory subject informatics for 15-years-old pupils in the AHS. In 1985 the introduction of this subject was considered a very progressive and debated measure. Till today the subject informatics is obligatory for all pupils in 9th grade. But the needs in a digitally penetrated world have changed. It is too late to begin with formal informatics education - as a prerequisite for IT literacy - at the age of 15 . Within their autonomy, the majority of the HS and AHS offer informatics lessons in lower secondary level. As a major result of the online research described in this paper, exactly one third of the pupils in lower secondary level in the AHS have no formal informatics education at all.

An international survey shows the trend for an integrated approach using IT (Key data, 2004). In some countries IT/informatics is part of a compulsory curriculum. Official recommendations regarding these approaches are fairly similar among the investigated 
countries. Among official objectives of curricula we find activities such as involving the proper use of software, information retrieval and communications networks for extending knowledge in various subjects. These goals are uniformly the most representative ones in compulsory education, irrespective of the level. In many countries, the amount of time set aside for direct informatics/IT instruction is very flexible. Only in a few countries, and particularly those of central and eastern Europe, there is a minimum annual number of hours to be marked for teaching IT/informatics as an independent subject. Whereas ICT/IT is the common term in many European countries, Austrian schools prefer the term informatics.

The situation in Germany is similar. The subject informatics has been implemented throughout the sixteen autonomous federal states very diversely. The situation is even more complex and inhomogeneous than in Austria. Although many efforts are being made to establish informatics as a subject of its own at lower secondary level (Gesellschaft für Informatik, 2004), only few federal states such as Saxony and Bavaria introduced informatics as an independent subject.

An educational system isn't worth a great deal
if it teaches young people how to make a living
but doesn't teach them how to make a life
Source unknown

\section{Autonomy in the Field of IT and Informatics}

"In 1995 a fundamental school reform started in Austria. It provided for autonomy of schools, giving them the possibility to develop their own characteristic school profiles and to establish areas of emphasis. In 1999 a new curriculum was introduced for the lower level of academic secondary schools and for general secondary schools. It consists of core and extension areas. On the basis of this curriculum, a new curriculum for the upper level was developed as well. It came into force in the school year 2004/2005. Another important step in this process of enhancing quality at school is the change from measuring input to measuring output. In this context, work is under way for establishing the educational standards for the fourth grade of primary school, general secondary school and academic secondary school. In this context it is also worth mentioning that the European Computer Driving License (ECDL) has developed into a best-practice model. Austrian pupils have passed a total of 300,000 individual modules since the year 2000 . Thanks to the initiative "eFit Austria", schools are very well equipped with PCs. In Austrian secondary technological schools one PC is available for every four pupils (Ministry of Education, 2003)". It should be added that within four years from 2003 on, the amount of passed ECDL modules in schools increased up to the total of more than 900.000 at the end of 2007 (Fig. 2).

Most likely, the following three guidelines with significant implications for ICT in education will also be maintained by the current federal government.

- Autonomy of schools to alter timetables and introduce new subjects will be enhanced. 


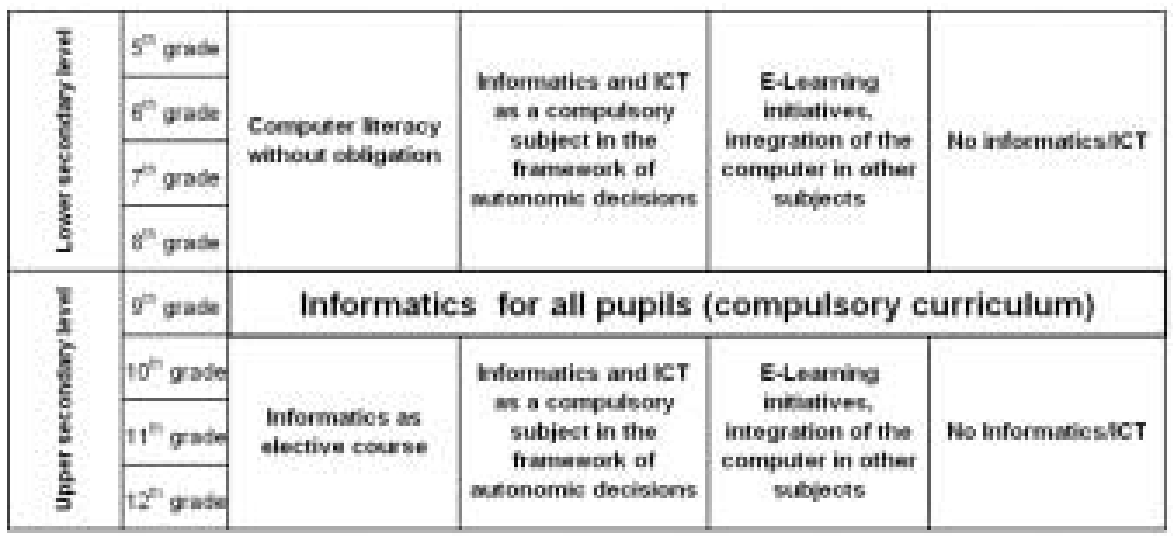

Fig. 2. Spectrum of Informatics/ITC in the AHS.

- The change from input orientation to measuring output in the form of educational standards will be put into effect in the subjects German, English and Mathematics.

- Offering the ECDL (and other IT-certificates) in schools will be supported further on.

At the lower level of academic secondary schools, autonomic decisions have already been made for some years. Although informatics does not explicitly occur in the canon of obligatory subjects, there have been many initiatives to establish the subject informatics in this age group. 10-14-year-old pupils today face a wide range of offer in the field of IT/informatics, varying from school to school. In this spectrum we find courses for typewriting, courses preparing the ECDL, non-obligatory tutorials, and even (in some federal states about 50\%) obligatory lessons in Informatics, which have been established at the expense of other subjects. Furthermore there are some models to integrate the computer and informatics methods in Mathematics, foreign languages or other established subjects.

More than a decade ago, this integrative approach was propagated and demanded by ministerial enactment. But in retrospective, one can state that this did not work in a satisfactory manner. The reasons were lack of appropriate standardized software, insufficient hardware at that time, and therefore, last but not least, the rather poor acceptance by the teachers involved. The situation in Germany is almost the same. The German initiative ITG (Informationstechnische Grundbildung) failed and still fails for the same reasons (Wilkens, 2000).

There is one thing even more vital to science than intelligent methods; and that is, the sincere desire to find out the truth, whatever it may be

\section{The Empirical Research}

Charles Sanders Pierce

Since the early 1990s (Haider, 1992) no other nationwide, empirically-based study regarding IT/informatics in academic secondary schools has been initiated. Reinforced 
school autonomy led inevitably to a certain lack of information. Currently, it is not even possible to quantify the extent of IT/informatics instruction in Austrians academic secondary schools. In Austria, empirical research in the field of IT/informatics is carried out, if at all, rather occasionally than systematically. Euphemistically it can be stated that the Austrian national educational research is in a rather early stage of development.

Being aware of this unsatisfying situation especially in the dynamic and unclear field of IT/informatics education, the author conducted a large-scale online survey among the 340 Austrian AHS (Gymnasium) in March and April 2007.

It is obvious that this risky undertaking had to be prepared carefully in order to achieve a reasonable response rate. The preparation of this survey comprised the key questions "what", "why" and "how". Long before the schools were invited to take part in this scientific research, it had been necessary to define some major hypotheses and research questions as basis for the concrete questionnaires. In the end, four wide-ranging questionnaires for school administration, informatics teachers, all students in 9th grade and a random sample of students in 10th grade, have been developed.

Designing such a complex survey is always a tightrope walk between gaining as much data as possible and not overstraining the willingness of the probands to fill in long questionnaires. In consideration of altogether more than 250 items, a very structured approach in designing the questions was absolutely necessary. Open questions allow more freedom, but are difficult to analyze. All items can be assigned to the categories demography, behavior, facts, attitudes and opinions. An analysis of the data meets the definition of an empirical study. "The empirical method ... is generally characterized by the collection of a large amount of data before much speculation as to their significance, or without much idea of what to expect ..." (Bridgman \& Holton, 2000). This study comprises aspects of a quantitative and qualitative research as well. On basis of the collected data, a contemporary theory about IT/informatics in academic secondary schools in Austria can be inferred.

The present study addresses too many issues as to be able to report all the results in this paper. Therefore, for this paper just a collection of the following interesting areas has been chosen:

- some information and statistics about carrying out the online survey in a social and technological context;

- background information such as IT-facilities at schools;

- data about formal IT/informatics education at lower secondary level;

- informatics education at upper secondary level focusing on the compulsory subject informatics in the 9th grade.

This research will also yield some useful spin-offs in the form of anonymized data. These raw data will be made available online and can serve as a mine of information for informatics lessons.

\subsection{Preparing and Conducting the Online-Survey}

In 2005 the initial plan to investigate all academic secondary schools in Austria, yielding an overall snapshot of their IT/informatics penetration and realization, already included 


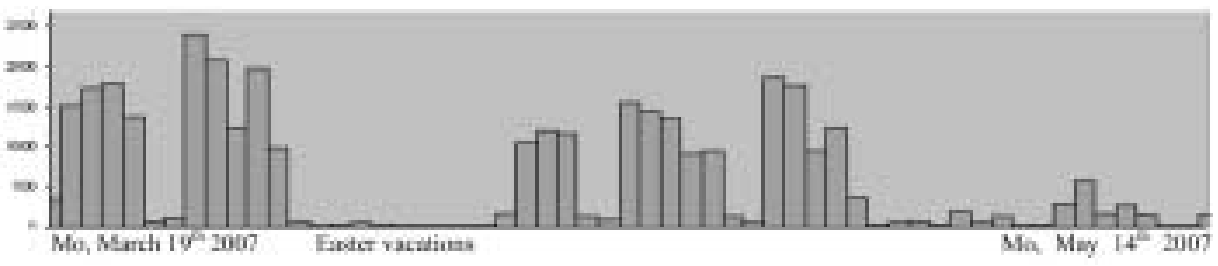

Fig. 3. Timeline of response and feedback.

the main research methodology: online questionnaires. The reasons for an online survey were evident.

- All 340 schools involved are already connected to the internet with an acceptable bandwidth.

- In spring 2007 there was not yet an over saturation with online-questioning. Due to more online-surveys in the future, it may be assumed that probands will be increasingly reluctant to fill out online-questionnaires.

- The amount of expected questionnaires required automatic collection of the digital data.

Parallel to the design process of the online-questionnaires, appropriate strategies to reach and convince the probands (school administrators, informatics teachers, students) had to be developed. Much importance was attached to provide for a reliable technical infrastructure, in order to make sure that things run smoothly.

There is no algorithm for developing optimal questionnaires for four different cohorts. Conducting such a big survey and addressing about 30.000 potential probands can also be considered as a social experiment with some imponderability. In disseminating the call for participation in that survey, the absolute key players were the headmasters. It was up to them to read the accompanying letters with benevolence and to distribute the printed invitations together with the access codes among the teachers. Simultaneously, an official electronical decree from the Ministry of Education supported the survey by recommendation.

Two weeks before the Easter holidays 2007 all 340 schools involved were informed and officially invited to take part in the survey. All information was and is still located on the project-website http://ahs.schulinformatik.at. The survey was accessible from mid March to mid of May. Within two weeks after the schools had been invited, about $40 \%$ of the response rate was reached. In the end, a polite reminder for those schools which had not responded yet yielded a (reasonable) response rate of about 9.400 filled-in online questionnaires (Fig. 3).

\subsection{Some Technical Facts}

The functionality of the web survey was developed with PHP scripts, embedded in singlepage HTML-questionnaires. After the login process with individual access codes the probands had full and simultaneous access to all items which all had been designed as 
non-mandatory. In view of the lengthy questionnaires this guaranteed a certain fairness in the sense that the probands knew very soon what was expected from them. After the submission of the filled-in web form the access key was voided by the system and the data were transmitted through the internet into the according flat tables of the MYSQLdatabase, where each field corresponded with the particular items.

From 340 academic secondary schools exactly half responded with at least one questionnaire. In total 9280 online-questionnaires have been filled-in, which represents an estimated overall response rate of 9280/30000 25\%.

In detail, 88 headmasters out of $340(\sim 26 \%), 410$ informatics teachers out of estimated $2000(\sim 20 \%), 9280$ students in the 9th grade out of about $25000(\sim 37 \%)$, and finally a random sample of 1640 students in the 10th grade out of about $9000(\sim 18 \%)$ responded.

You cannot feed the hungry on statistics

\section{Preliminary Results}

The process of collecting a huge amount of highly structured data in form of a large-scale online-survey was finished by mid May 2007. After investigating the quality of data, the first preliminary results will be presented in this paper. Mainly based on univariate data analyzing and some content analyzing, they draw a very inhomogeneous picture of the current situation about IT/informatics in Austria's academic secondary schools. Further and deeper statistical evaluations and analyses will follow in other publications.

\subsection{Facts about the IT Infrastructure}

Although investigation of IT-facilities is not primarily in the scope of this research, it sheds a very characteristic light on the unequal conditions schools in Austria have to cope with. One important indicator for the quality of ICT penetration is the student/computer ratio. The study shows an average of 12 students per computer. It is not only this abstract figure which is disappointing, but it is the big differences among the particular schools. The best equipped ones show a ratio of $5: 1$ and the worst more than $20: 1$. At this point the question arises if this is an acceptable situation. Actually, already in 2005 the ministry of education announced an Austrian average of 8 students per computer. The study revealed other figures, at least for academic secondary schools. The last considerable central investment (5.3 millions Eu, 13.000 Eu per school) took place in 2003 where all 340 AHS could upgrade their computer equipment. In the last year, further $10.000 \mathrm{Eu}$ per school could be spent on computers and beamers in addition to the normal budget. In view of the enormous challenges to maintain a working IT infrastructure, not only for the subject informatics but more and more for the ICT penetration in the whole learning process (e-learning), these investments are rather poor. The questionnaire for the headmasters clearly showed that academic secondary schools face severe problems to keep pace with modern and adequate IT equipment. 


\subsection{Results about Informatics at the Lower Secondary Level}

Trying to give a reasonably accurate overview about diverging choice of formal informatics instruction at lower secondary level is practically impossible. The problem is multi-dimensional. Firstly, there are informatics lessons at the expense of other subjects (compulsory and legal within school autonomy) and three types of additional elective courses, and secondly, IT/informatics classes take place in different grades with a different amount of hours per week. Within the responding schools there are hardly two with the same profile of timetables regarding IT/informatics lessons. In this context, a Latin proverb is suitable: "Variatio delectat!".

As a consequence, at the end of lower secondary level there is a big digital gap among the 14-years-old pupils. More than one third of all pupils have not been educated in any formal IT/informatics lesson, whereas more than $10 \%$ attended in total 6-8 hours within 4 years. These are hard facts which have been proved by similar results from the questionnaire for the students in grade 10 (Fig. 4).

The students in the 9th grade were asked if they favored a compulsory subject IT/informatics with an amount of 2-4 hours weekly in lower secondary level. About 2/3 agreed and the rest disagreed. Not surprisingly, this suggestion also obtained approval by approximately $80 \%$ of the informatics teachers, and about $60 \%$ of the headmasters. Asked about introducing educational standards for IT/informatics for 14 years-old pupils, about half of the headmasters could not decide. The other half could imagine such standards according to recommendations by the Ministry of Education.

Another question for the 15-years-old students referred to the learning outcome of formal IT/informatics lessons at lower secondary level. The answer was rather disillusioning. Only $1 / 3$ claimed that they had learned much in these lessons, and not less than $50 \%$ claimed to have made only little progress. About $10 \%$ asserted that they learned nothing at all. Considering these results, one could doubt the quality and sustainability of IT/informatics education in lower secondary education. Almost $50 \%$ stated that they acquired computer competence by themselves whereas the other $50 \%$ do not claim to be successful autodidacts.

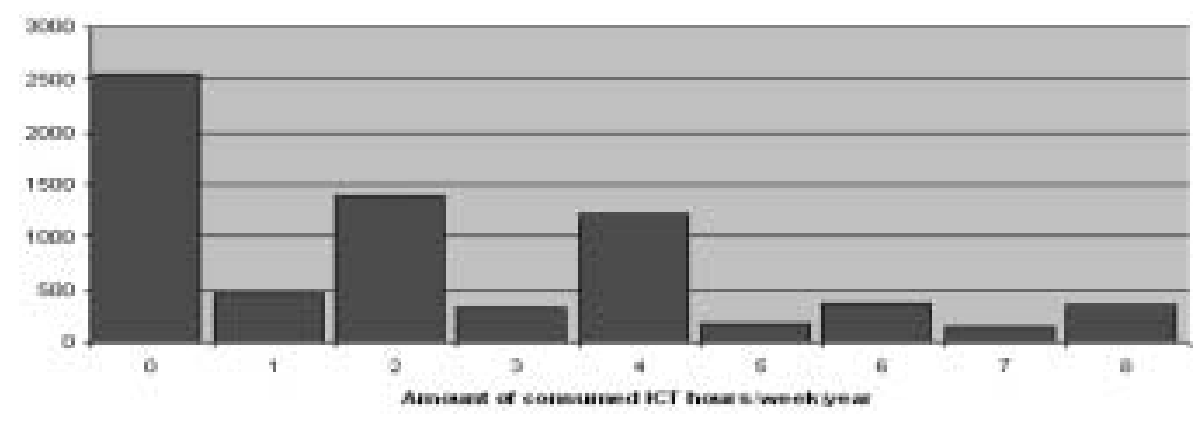

Fig. 4. Distribution of formal IT/informatics instruction in lower secondary level. 


\subsection{The Compulsory Subject Informatics in the 9th Grade}

In order to get a reliable and comprehensive picture of the obligatory subject informatics in the 9th grade, which is the only constant of informatics instruction at academic secondary schools in Austria, teachers as well as students in the 9th and 10th grade have been questioned about this subject comprehensively.

The students' attitude in the 9th grade yielded that almost $60 \%$ are interested in that subject whereas $35 \%$ are definitely not. $5 \%$ could not decide. $7 \%$ consider informatics as their favorite subject and for $25 \%$ it ranks among the favorite subjects. Due to the lack of former studies we lack comparisons and it is not possible to classify this result as good or bad.

For more than $60 \%$, the subject informatics is considered easy, and less than $10 \%$ find it difficult. This corresponds with the obviously excellent grades. About $80 \%$ were marked with 1 or 2 (very good and good), 19\% obtained the grades 3 and 4 (satisfying and sufficient) and only $1 \%$ got the grade 5 , which means insufficient. This correlates with the students' answers to the question if their informatics teachers are strict. One third of the cohort asserts that informatics teachers deal severely with them.

About $20 \%$ intent to enroll for the elective subject informatics in the grades 10 to 12 , and about $15 \%$ could imagine taking the final exam in informatics, among them $23 \%$ male and (only) $6 \%$ female students. This reveals significant gender-specific differences in terms of attitude towards the subject informatics also in Austria.

A curriculum (Marsh \& Willis, 1999) is defined as "an interrelated set of plans and experiences that a student undertakes under the guidance of the school. Moreover four types of curricula are distinguished: the planned, the enacted, the experienced and the hidden curriculum. Nobody would doubt the importance of enacted (written) curricula as tools for normalizing and controlling the educational tasks of schools. But there are severe doubts about their efficacy to induce effective teaching processes and to produce the desirable learning outcomes."

In Austria intense debates on curricula are going on. The buzzword in this context is "educational standards". Obviously these standards aim at the crucial part of the curriculum, namely the definition of its objectives, which are often expressed in terms of learning outcomes.

In contrast, the official curriculum for the 9th (Curriculum, 2003) grade has a very wide scope. The main part of the curriculum, concerning the subject matters, consists of the following instructions.

The students should be able to:

- manage information and organize their learning themselves with suitable software;

- convert existing sources of information and produce different information representations on the basis of previous knowledge;

- use and systemize contents and structures as well as results, and to present their individual work in a multimedial way;

- handle standard software for written correspondence, for documentation, for the publication of work, for multimedia presentation as well as for communication; 
- use calculation models and evaluate and interpret the results and to use a simple data base;

- to know substantial terms and methods of computer science and their typical mindsets, their historical development as well as their technical and theoretical basis;

- get insight into the basic principles of automats, algorithms and programs;

- know substantial measures and legal bases in connection with data security, data security and copyright;

- know about the effects of information technology on employment and the society.

There is no further legislative regulation and specification for the informatics teachers involved. This curriculum gives an ample scope for interpretation. Therefore the teachers' responses in the online survey were all the more interesting. Asked about this curriculum, about $60 \%$ of the teachers like its wide scope, and about $20 \%$ want to leave it unchanged. For not more than $13 \%$ the curriculum in this form is dispensable and about $20 \%$ would appreciate more details. Interestingly, the hypothesis that this curriculum would meet with a broad disapproval among Austrian informatics teachers could not be verified.

Textbooks are often regarded as hidden curricula. But this is definitely not the case in informatics education. The following figures demonstrate impressively the minor role of textbooks in informatics teaching at the 9th grade. Teachers who taught in the 9th grade in 2006/2007 (absolute figures) used in their lessons (Table 1).

Almost 50\% of the teachers are interested in an appropriate, alternative textbook. One obvious reason for this respectable number of teachers might be that they consider textbooks as reliable guides in view of the huge amount of digital information which might obscure learning objectives.

\subsection{Findings about Attitudes towards the ECDL Certificate}

Since 1998 a remarkable development in Austrian's educational system has taken place. Under the patronage of the Ministry of Education the European Computer Driving License (see http: / /www. edu.ecdl .at) is exerting a veritable influence on the Austrian school system. The association "ECDL at schools Inc." has developed to a very successful organization in which many teachers from academic secondary schools are involved.

Table 1

Teaching material in the 9 th grade

\begin{tabular}{lccc}
\hline Teaching Material is used ... & often & sometimes & Never \\
\hline Textbook & 13 & 63 & 209 \\
ECDL-related instructional books & 33 & 103 & 159 \\
Material from the internet & 146 & 63 & 11 \\
Self-produced learning materials & 249 & 71 & 3 \\
Articles from computer magazines & 40 & 154 & 106 \\
Other informative books & 46 & 162 & 96 \\
\hline
\end{tabular}


The ECDL certificate is offered at all stages of secondary education and some types of schools (not officially the AHS) even adapt the ECDL core syllabus as basis for the subject informatics. This is unique in Europe. If speaking of basic IT-skills, one cannot ignore the ECDL. Together with its global extension ICDL (International Computer Driving License) it is available in about 140 countries worldwide and has been translated into 36 languages so far. Currently, the ECDL/ICDL is the world's leading end-user computer skills certification program. With presently almost 6 million participants, it offers the world's largest vendor-neutral end-user computer skills certification and is internationally recognized as the global benchmark in this area. About $30 \%$ of the responding informatics teachers asserted that they are ECDL certified and about $13 \%$ have the license to conduct external ECDL examinations at schools.

One important part of this research consists of the investigation of the teachers' attitudes towards the ECDL and the impact of the ECDL in academic secondary schools. Additionally, its congruence with the official curriculum in the 9th grade is of interest (Table 2).

Table 2 mirrors the core attitudes of informatics teachers in Austrian academic secondary schools towards the ECDL. It is remarkable that the external examination system and the good orientation for teaching it provides are accepted very well. On the other hand the majority of informatics teachers object to the equalization of ECDL and informatics education in the 9th grade. Moreover, most of the teachers do not think that a positive mark at the end of 5th grade and the ECDL certificate are of the same value.

Although there is a steady relocation of ECDL examinations from the upper secondary level to the lower secondary level, there are still many examinations in the age-group of 15 and 16. About $5 \%$ of the students at 9 th grade have finished all 7 modules, whereas within a year this percentage has increased to about $20 \%$. These figures falsify the hypothesis that preparing for the ECDL is dominating informatics lessons. Obviously, but this needs a further analysis of the data, there are considerable regional differences concerning the acceptance and penetration of the ECDL.

Table 2

Attitudes of informatics teachers regarding the ECDL

\begin{tabular}{lccccc}
\hline & yes & rather yes & rather no & no & no response \\
\hline The ECDL provides good orientation for pupils and teachers & 179 & 149 & 23 & 13 & 44 \\
The ECDL is necessary for a (later) profession & 77 & 134 & 87 & 67 & 43 \\
The external examination system is very good & 171 & 127 & 35 & 27 & 48 \\
The ECDL should be compulsory at lower secondary level & 40 & 59 & 102 & 164 & 43 \\
A positive mark in the informatics class (9th grade) & & & & & \\
can replace the ECDL certificate & 35 & 50 & 97 & 184 & 42 \\
The costs of the ECDL are justified & 60 & 114 & 77 & 81 & 76 \\
The contents of the ECDL should go more in depth & 61 & 101 & 111 & 46 & 89 \\
The current conditions in the context of the ECDL fit & 50 & 110 & 77 & 56 & 115 \\
\hline
\end{tabular}




\subsection{Investigating the Contents}

In the last part of this section of the paper we "attempt the impossible" of getting some insight which subject matters are taught nationwide in informatics lessons at the 9th grade. It is beyond the scope of this paper to explain all approaches and results of this challenging task in detail.

Fig. 5 gives an insight into the contents and modules taught in the first and second semester. The underlying information stems from the questionnaire for the about 400 responding teachers.

Not surprisingly, Fig. 5 points out the domination of standard software. A deeper investigation of the data in terms of software products showed that the penetration of Microsoft Office applications is more then $90 \%$. Due to a contract of the Ministry of Education with Microsoft about a general license, open source does not play an important role currently.

Teaching programming in the 9th grade, although decreasing in the last years, still represents a remarkable module. But further investigations will most likely prove that in many courses this topic is not taught at all. Preferred programming languages are Delphi, Visual Basic and Turbo Pascal.

Most areas of the curriculum seem to be covered, but we do not know anything about what is really going on in nearly two thousand particular informatics classes in Austria's academic secondary schools. What do the students really know after this year of informatics education? What are the outcomes? Understandably, giving a reliable answer to this question goes far beyond this research and needs expensive testing.

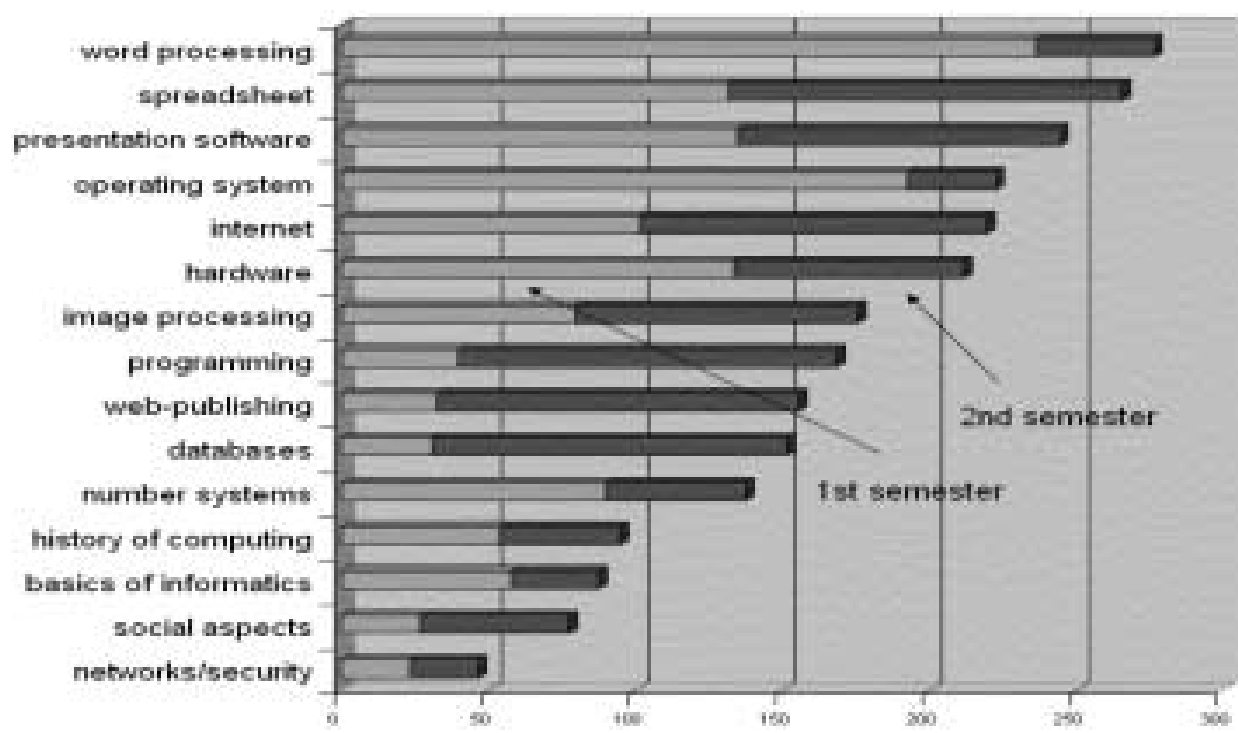

Fig. 5. Subject matters of the informatics in the 9th grade and its semester distribution. 
To obtain more information about detailed contents taught in the 9 th grade, 40 items in the form of statements in the students' questionnaire have been formulated. They could decide between "it is very easy for me“" "I knew it already", "I have heard of it, but ..." and "I don't know what this is about".

This method of self-assessment, which is also used in thematical questionnaires of the PISA study, leads to the following exemplary results.

$71 \%$ do not know the persons Hollerith, Zuse, v. Neumann, $69 \%$ have not executed one single SQL command, 69\% do not know what an array is, 64\% do not know the function of the lookup-function in Excel, 61\% have never designed an (easy) ER-diagram, 59\% cannot define an algorithm, 58\% have never heard of ASCII, 58\% do not know what phishing is, 57\% have never applied CSS $(n=1640)$.

These are a few results which only show the "the tip of the iceberg" and should make us cautious as to expect too much sustainable IT competence and knowledge after formal informatics lessons in the 9th grade.

In the random sample of 1640 responding students $28 \%$ attend elective courses of informatics in the 10th grade. This indicates a slight bias because not more than $20 \%$ of the students enrol in these courses. We can infer that the exemplary results even show a flattering picture of the real situation.

One might object that knowing of Hollerith, Zuse and v. Neumann and heaving heard of SQL commands are indespensible for 15 years old students. Is Austria in the lucky position that about one third of the students at secondary academic schools have heard about history and the databases in their informatics lessons? No way!

Firstly, online questionnaires cannot replace (costly) testing at schools. It can be doubted that actually $30 \%$ have executed SQL commands explicitly. And secondly, this detail raises the question about the curriculum and the inferred and intended objectives. The corresponding part in the curriculum is "The students should be able ... to use a simple data base."

I declare open the debate on, for example, knowing about SQL-queries as an indispensable part of teaching databases in the 9th grade not only in Austrian schools. Clearly, the necessary discussion on curriculum issues and their impact and commitment, respectively the intended and inferred competencies cannot be conducted in this paper. But this should happen somehow and some time, especially in Austria.

\section{Discussion}

Let us teach students, not subjects

IT and informatics education in secondary education still develops dynamically. Increasing school autonomy in Austria has led to a conglomerate of schools with different profiles. As the paper illustrates, IT and informatics contribute to it extensively. The survey shows that especially lower secondary education is affected in a way which should be discussed in the near future. 
Different autonomous approaches at schools in implementing IT/informatics lessons do not guarantee that all pupils are provided with necessary IT competencies. Therefore an undesirable digital gap between the pupils at the end of lower secondary level is programmed. Actually, more than one third of the pupils pass lower secondary level without any formal IT instruction. Educational IT standards, similar to, but not identical with the ECDL, could solve that problem.

The dissemination of the ECDL in Austrian schools is well developed, but it does not play a dominant role in academic secondary schools. Future developments and the influence of this certificate on regular informatics lessons are difficult to predict, but especially at lower secondary level the syllabus of the ECDL is widely congruent with the school-specific curricula of IT/informatics lessons.

The compulsory subject informatics in the 9th grade plays the key role in all concepts of consolidating IT/informatics education in academic secondary schools. As long as teachers cannot rely upon a minimum of prior IT knowledge from lower secondary education, ambitious informatics lessons at this stage are hardly feasible. But these are necessary to impart to our students a proper and comprehensive picture of informatics beyond mere product training.

I am optimistic and have reason to believe that these visions will come true, somehow and some time, preferably in the near future.

\section{References}

Baumert, J. (2003). In Nelson Kilius et al. (Eds.) Die Zukunft der Bildung. Suhrkamp, Frankfurt am Main. Bridgeman, P.W., and G. Holton (2000). Encyclopedia of Science and Technology. McGraw-Hill. Empirical Method, AccessScience.

http: / /encyclopedia. thefreedictionary.com/empirical+method (1.8.2007).

Cuuriculum (2003). http: / / www.gemeinsamlernen. at (1.8.2007).

Eisenberg, M.B., and D. Johnson (2002). Learning and Teaching Information Technology Computer Skills in Context.

Gesellschaft für Informatik: Digitale Spaltung verhindern - Schulinformatik stärken! Memorandum, Ulm (2004).

Haider, G. (1992). Schule und Computer. Österreichischer Studienverlag, Innsbruck.

Key Data. Key Data on Information and Communication Technology in Schools in Europe Eurydice, Brussels (2004).

Ministry of Education. Development of Education (2003).

http: / / www. fulbright.at/dokumente/bildungsentw_en.pdf (1.8.2007).

Marsh, C.J., and G. Willis (1999). Curriculum Alternative Approaches. Ongoing Issues. NJ, Prentice-Hall.

Micheuz, P. (2005). 20 Years of computers and informatics in Austrian's secondary academic schools. In R. Mittermeir (Ed.) From Computer Literacy to Informatics Fundamentals. Springer, Berlin, pp. 20-31.

Micheuz P. (2007). Ein Beitrag zur informatischen Bildungsforschung: Informatikunterricht zahlt sich aus. In Didaktik der Informatik in Theorie und Praxis, p. 325; Lecture Notes in Informatics, GI, Bonn.

Pisa. Longer Term Strategy of the Development of PISA, 20th meeting of the PISA Governing Board.

3-5 October 2005, Reykjavik, Iceland.

http: / / www.pisa. oecd. org (1.8.2007).

Wilkens, U. (2000). Das allmähliche Verschwinden der informationstechnischen Grundbildung. Shaker Verlag $\mathrm{GmbH}$. 
P. Micheuz is an Austrian teacher for mathematics and informatics at the Alpen-AdriaGymnasium Völkermarkt since 1979. He is actively involved in teachers' education for informatics since 1987, and since 2000 he also is in charge for teacher education courses at the Alpen-Adria-University Klagenfurt. His scientific working areas encompass empirical studies within the area of informatical education such as didactics of informatics and e-learning. As generalist and digital immigrant, he publishes in the domains of informatics education, standards and e-learning. He is one of Austria's representative in IFIP TC 3 WG 3.1 and keeps international contact within the national and international scientific community of informatics didacts.

\section{Informatikos mokymo Austrijos akademinėse vidurinėse mokyklose klausimai}

\section{Peter MICHEUZ}

Akademinès vidurinès mokyklos (vok. kalba äGymansiumô - gimnazijos) Austrijoje atlieka svarbu vaidmenị švietimo sistemoje, kuri yra gana ịvairialypè. Šiose mokyklose mokosi 10 18 metu amžiaus moksleiviai, kurie igyja pagrindinį ir vidurinị išsilavinimą. Per daugiau nei dvidešimt metu informatika, informacinès technologijos (IT) ir kompiuteriai vis labiau ịsiskverbe į vidurinę mokyklą. Austrijos akademinès vidurinès mokyklos yra nevaržomos sprendžiant sunkumus savarankiškai. Šiame straipsnyje nagrinejama dabartinè informatikos mokymo situacija mokyklose, ypatingą demesi skiriant devintajai klasei. Austrijoje, informatikos privalomas kursas yra tik šio amžiaus grupejje (prisiminkime, tai äPisa-amžiusô). Akademiniu viduriniu mokyklu vadovybės savarankiškai nusprendè padidinti IT ir informatikos pamokų skaičių žemesnėse klasėse. Neseniai buvo atliktas nacionalinis tyrimas internete. Straipsnyje pateikiamos šio tyrimo preliminarios išvados. 